\title{
Learning styles of nursing graduate students enrolled in a master's degree program
}

\author{
Uma investigação sobre os estilos de aprendizagem de alunos do programa de mestrado em \\ enfermagem \\ Investigación sobre los estilos de aprendizaje de alumnos del programa de maestría en enfermería
}

\section{Leides Barroso Azevedo Moura1}

\begin{abstract}
Objective: The purpose of this study was to identify the learning styles of nursing graduate students enrolled in a master's degree program at a public USA university. Methods: The study was guide by the individual and social constructivism framework. Data were collected with a personal data sheet and with the Inventory of Learning Process-Revised (ILP-R), coded and entered into the Statistical Package for the Social Science (SPSS) data processor. Results: Although there were no statistical significant differences between graduate student regarding learning styles, the study's findings suggest a trend toward elaborative, in depth, and student-centered learning styles. The least used learning style was the methodical approach or literal memorization. In addition, there were positive relationships between and among sub-scales of the ILP-R. Conclusion: The findings of this study might be useful to nursing faculty because they provide some insights about the learning styles to which nursing graduate students are more likely to adhere.
\end{abstract}

Keywords: Learning; Education, nursing, graduate/methods; Students, nursing

\section{RESUMO}

Objetivo: Este estudo objetivou identificar os estilos de aprendizagem dos alunos do programa de mestrado em enfermagem numa universidade publica localizada na região nordeste dos Estados Unidos. Métodos: O referencial teórico adotado foi a teoria de construção individual e social do conhecimento chamada construtivismo. O Inventario do Processo de Aprendizagem - Versão Revisada (ILP-R) e dados demográficos foram codificados e analisados utilizando o Pacote Estatístico das Ciências Sociais (SPSS). Resultados: Preferência nos tipos elaborativo, agente e profundo de aprendizagem com menor uso do tipo metódico e de memorização literal foi percebido, porém sem significância estatística. Comprovou-se um relacionamento positivo entre algumas sub-escalas de aprendizagem. Conclusão: O resultado deste estudo será útil para professores universitários uma vez que o processo de ensinar começa na maneira como respondemos às necessidades dos nossos alunos.

Descritores: Aprendizagem; Educação de pós-graduação em enfermagem/métodos; Estudantes de enfermagem

\section{RESUMEN}

Objetivo: En este estudio se tuvo como objetivo identificar los estilos de aprendizaje de los alumnos del programa de maestría en enfermería de una universidad pública localizada en la región noreste de los Estados Unidos. Métodos: El referencial teórico adoptado fue la teoría de construcción individual y social del conocimiento llamada constructivismo. El Inventario del Proceso de Aprendizaje - Versión Revisada (ILP-R) y los actos demográficos fueron codificados y analizados con el empleo del Paquete Estadístico de las Ciencias Sociales (SPSS). Resultados: Se percibió una tenue preferencia por los tipos elaborativos, profundo, y agente de aprendizaje con menos uso del tipo metódico y de memorización literal. Esta diferencia no representa significancia estadística. Se comprobó una asociación positiva entre las sub-escalas de aprendizaje. Conclusión: El resultado de este estudio será útil para los profesores universitarios dado que el proceso de enseñar comienza por la forma cómo respondemos a las necesidades de los alumnos.

Descriptores: Aprendizaje; Educación de postgrado en enfermería/métodos; Estudiantes de enfermería

${ }^{1}$ Clinical Nurse Specialist and Master in Science of Nursing at Western Connecticut State University. 


\section{INTRODUCTION}

Students at the graduate level should be able to monitor their learning and actively find answers to their questions with greater skill than students at the undergraduate level, who may still need help in developing their ability to absorb information, think about information, and evaluate the application of information in real-world situations. This study examined the learning process of nurses in a master's degree program. The research reported in the nursing literature concerning learning style has been limited to undergraduate nursing students; therefore, a study of the learning styles of nursing students in graduate programs would expand knowledge related to this important topic.

In a pluralist society where knowledge drives everything, even the globalization of the economy, the ability to learn is essential ${ }^{(1)}$. Learning in today's information era requires ceaseless attention and the ability to change direction with little advance notice. The growing information and technology explosion has caused an increased need for learning.

Students need to feel confidence about themselves as learners ${ }^{(2)}$. It is important that they acquire the ability to reflect on their own learning skills and progress gradually from a passive learning position to an active level of participation in their own learning process. Good learners do not passively accept information. Active learning is a process of knowledge construction, where learners can be active designers and contributors rather than passive consumers ${ }^{(2)}$.

Active learners are needed for the nursing profession because it is engaged in an educational pursuit to provide complex nursing care that requires specialized skills and a dynamic level of knowledge. In actual practice, the changing arena of health care systems demands an increased ability to learn on the part of all health professionals.

There is a need to find ways and to encourage the two different cultures of 'students' and 'faculty members' to dialogue productively and to actively participate in defining the future of nursing. Analyzing how students learn, as well as acknowledging and attempting to understand the socially conditioned knowledge they bring to the classroom, can help lead to effective teaching. Learning style assessment is a tool designed to give teachers an accurate flow of information on the nature of student learning. The results of this study can be used to facilitate dialogue between students and faculty members on the nature of the learning process, and what can be done to improve it.

\section{Postmodern Learning Paradigm: Social Constructivism}

The impact of constructivism has been explored in the field of philosophy ${ }^{(3-5)}$; however, pedagogy in the United States has been dominated by the behavioristic model $^{(\sigma)}$. Some encouraging instructional strategies that reflect the constructivist view of learning process emerged two decades ago ${ }^{(7-9)}$. Unfortunately, in the nursing literature, no studies could be located that describe the impact of constructivism on nursing education.

The constructivist approach in education is a postmodernist idea that has emerged from the work of psychologists and educators, such as Bruner ${ }^{(10)}$, Piaget ${ }^{(11)}$, and $V_{\text {ygotsky }}{ }^{(12)}$. While Piaget emphasizes cognition as a construction process taking place within the learner, Vygotsky's theory places more emphasis on the social context of learning; his theory is known as social constructivism.

Vygotsky ${ }^{(13)}$ emphasized the critical importance of culture and the relevance of social context for cognitive development. In this framework, teacher and students are active and involved elements in the learning process. While for Piaget learning and development is a cognitive activity, for Vygotsky learning and development is a social collaborative activity. Thus, the main aspect of Vygotsky's theoretical framework is that social interaction plays an essential role in the development of cognition.

While the traditional objectivist view of learning is concerned with the object of one's knowing and assumes that the knowledge being conveyed is placed in the learner's mind as it was presented, constructivism is concerned with how one constructs knowledge and the process of "meaning making" from external sources ${ }^{(14)}$.

This new pedagogy encourages educators to retreat from a "banking system of education" in which the riches of knowledge are deposited in the empty vault of a learner's mind. In the "banking" method of instruction, the educator assumes the role of the superior, and the passive learner receives deposits of pre-selected, static, and ready-made knowledge ${ }^{(15)}$.

The hypotheses tested in the study were (1) that students enrolled in a program leading to the master of science in nursing (MSN) degree will have higher scores on reflective learning, represented by deep and elaborative learning styles, than on agentic learning style; (2) that there will be a higher score on the deep and elaborative learning styles among students who have more years of professional practice in nursing than among students who have fewer years of practice; (3) that there will be higher scores on the agentic learning style among students who that have completed fewer credits toward the MSN than among students who have more such credits; (4) that there will be a positive relationship between scores on the academic motivation scale and the self-esteem scale among the graduate nursing students.

\section{METHODS}

This study used a descriptive cross sectional design to describe the learning styles of students $(N=50)$ engaged 
in graduate education in nursing enrolled during one semester at a state university in New England, United States of America. Approval to conduct the study was obtained from the Institutional Review Board of the mentioned university. Students were at various stages in their progress toward the master science in nursing (MSN) degree. They were selected on the basis of participation in courses offered in the spring semester. Fifty of the 68 students registered for spring classes answered the questionnaires (73,5\%). The Learning Style Inventory and personal data sheet were distributed late in the spring semester in a classroom setting. The inventory was to be completed during class time.

Participants received standardized information about the study and informed consent was signed. A copy of results and suggestions about learning style improvement was made available at the end of the study to all individual students who provided an address for that purpose.

The Statistical Package for the Social Science (SPSS) was used to perform all data analyses in this study. The steps included univariate analysis, bivariate analysis, and multivariate analysis in order to determine the frequencies of, and relationship between variables. Reliability testing for internal consistency of the ILP-R and its sub-scales was performed using Cronbach's alpha coefficient.

\section{Instrument}

A revised version of the Inventory of Learning Process-Revised that was first published in 1977 was used in this study ${ }^{(16)}$. The authors of the inventory analyzed students' responses to statements concerned with academic study and described four styles, classified as Deep Processing, Elaborative Processing, Fact Retention, and Methodical Study.

The more recent ILP-R is a revised and expanded 90item version of the original 62-item Inventory of Learning Process ${ }^{(17)}$. It is a self-administered questionnaire to measure a student's preferred learning style. Schmeck and GeislerBrenstein's model of learning proposes five styles: Deep Learning (10-item), Elaborative Learning (10-item), Agentic Learning (10-item), Methodical Learning (5-item), Literal Memorization (5-item). The revised Inventory of Learning Process incorporates self-concept and motivational scales, allowing the assessment of individual facets as well as higherlevel constructs: self-efficacy organization (5-item), self-efficacy critical thinking (5-item), self-efficacy fact retention (5-item), academic self-esteem (5-item), academic motivation(15-item), self-assertion (5-item), and conventional attitudes (5-item). In addition, the ILP-R includes a lie sub-scale (5-item) to assess accuracy of the answers.

Internal consistency reliabilities (Cronbach alpha) for the ILP-R, range from .72 to .87 for the main scales, and from .58 to .88 for the subscales ${ }^{(16)}$. The instrument requires approximately 10-15 minutes to be completed.
In general, Deep Learning assesses two different aspects, labeled semantic and critical. The semantic facet involves a preference for knowing about things rather than knowing things directly from practical experience. The critical facet of Deep Learning involves critical analysis of theories. Students who score high on this subscale tend to question the reasons behind each theory.

Elaborative Learning is characterized by a preference for dialectical learning, which can emphasize either theoretical or experiential forms of knowledge. Students who use elaborative processing tend to have more integrated self-concepts and use self-reference as a learning tactic. Elaborative Learning also assesses two aspects, labeled episodic and self-actualizing. The episodic involves imagination and use of memory in problem-solving situations. Self-actualizing learning emphasizes selfexpression and personal development, and relies on intuition rather than logic.

Agentic Learning, on the other hand, is characterized by a propensity toward a realistic approach, where learning is task-oriented and responsive to external circumstances. Serial and analytic are the two subscales of Agentic Learning. Serial involves scheduling and programming of activities and academic tasks to be done. Analytic emphasizes logical decomposition of the constituents of tasks using appropriate tactics.

Methodical Learning focuses on techniques rather than content. Students who score high on this subscale show a preference for traditional methods of study.

The final dimension of learning is called Literal Memorization. This scale identifies students who repeat information the teacher provides. Unfortunately, many educators like to see this as a kind of learning style. They believe that they are educating; however, rather than education this is a process of oppression.

\section{Personality Dimensions}

In addition, the ILP-R measures related abilities to motivate self, and such personality dimensions of school learning as Academic Self-Efficacy (Cognitive Organization, Critical Thinking, Fact Retention), Academic Motivation (Interest, Personal Responsibility, and Effort), Self-Assertion, and Conventional Attitudes.

\section{RESULTS}

Descriptive statistics were used for the report of background demographic data concerning the gender, age, number of graduate credits completed, number of years of professional practice as a registered nurse, highest degree completed, and the number of years between baccalaureate graduation and initiation of study toward the MSN. The demographic profile of the respondents in this sample indicated $96 \%$ were female with an average 
age of 38 years (range 24-59 years old). The mean number of graduate credits completed was 14 (SD 12.85). The total years of nursing experience for subjects ranged from 2 to 34 years, with a mean of 13 years. Forty percent had up to 10 years of experience, while $44 \%$ had between 11 and 20 years of experience.

Hypothesis 1 was tested using the t-test. Table 1 shows that there was no significant difference in scores on either the deep or elaborative learning styles and the agentic learning style. Even though, the graduate nursing students had higher scores on deep $(60 \%)$ and elaborative $(58 \%)$ than on agentic learning (48\%), the low correlation between Deep, Elaborative, and Agentic did not suggest statistical difference. Hypothesis 1 was rejected.

Table 1 - Comparison of scores on Deep and Elaborative Learning and Agentic Learning (USA-2001)

\begin{tabular}{lccccc}
\hline & & & \multicolumn{3}{c}{ Mean } \\
Scale & $\mathrm{T}$ & Df & 2-tailed & Difference & \\
\hline Agentic & 21.115 & 49 & .000 & 6.76 & N.S \\
Deep & 23.166 & 49 & .000 & 7.02 & N.S \\
Elaborative & 31.905 & 49 & .000 & 7.66 & N.S \\
\hline
\end{tabular}

Results of the one-way analysis of variance (ANOVA) after organizing the data on years of professional practice into four groups, each representing $25 \%$ of the sample (2-5 years experience, 6-14 years experience, 15-19 years experience, 20-34 years experience) shows that there was no significant difference in deep and elaborative learning scores when respondents were grouped on the basis of years of experience in professional practice. Hypothesis 2 was rejected. Results are depicted in Table 2.

Table 2 - One Way ANOVA for Years of Experience in Nursing and Deep and Elaborative Learning Style. (USA, 2001)

\begin{tabular}{lcrrc}
\hline $\begin{array}{l}\text { Deep } \\
\text { Learning }\end{array}$ & $\begin{array}{c}\text { Sum } \\
\text { of } \\
\text { Square }\end{array}$ & Df & $\begin{array}{c}\text { Mean } \\
\text { Square }\end{array}$ & F \\
\hline Between & 12.539 & 8 & 1,567 & 1.155 N.S. \\
$\begin{array}{l}\text { Groups } \\
\text { Within }\end{array}$ & 55.641 & 41 & 1,357 & \\
$\begin{array}{l}\text { Groups } \\
\text { Total }\end{array}$ & 68.180 & 49 & & \\
$\begin{array}{l}\text { Elaborative } \\
\text { Learning }\end{array}$ & & & & \\
$\begin{array}{l}\text { Between } \\
\text { Groups }\end{array}$ & 7.036 & 7 & 1.005 & .690 N.S. \\
$\begin{array}{l}\text { Within } \\
\text { Groups }\end{array}$ & 61.144 & 42 & 1.456 & \\
Total & 68.180 & 49 & & \\
\hline
\end{tabular}

Hypothesis 3 was tested using one-way analysis of variance (ANOVA) after organizing the data on number of credits completed into three groups, each representing approximately $33 \%$ of the sample ( $0-3$ credits; $6-12$ credits; $15+$ credits). Results are depicted in Table 3 . There was no significant difference in scores on the agentic learning style when respondents were grouped on the basis of number of credits completed towards the MSN. Hypothesis 3 was rejected.

Table 3 - One Way ANOVA for Credits Completed Toward the MSN and Agentic Learning Style (USA, 2001).

\begin{tabular}{lrccc}
\hline $\begin{array}{l}\text { Agentic } \\
\text { Learning }\end{array}$ & $\begin{array}{c}\text { Sum of } \\
\text { Square }\end{array}$ & Df & $\begin{array}{c}\text { Mean } \\
\text { Square }\end{array}$ & F \\
\hline $\begin{array}{l}\text { Between } \\
\text { Groups }\end{array}$ & 5.316 & 8 & .664 & 1.118 N.S. \\
$\begin{array}{l}\text { Within } \\
\text { Groups }\end{array}$ & 24.364 & 41 & .594 & \\
Total & 26.680 & 49 & & \\
\hline
\end{tabular}

The hypothesis 4 was tested using the Pearson productmoment correlation statistic, and is reported in Table 4. There was a moderately strong positive correlation between scores on the academic motivation, interest subscale and scores on the academic self-esteem scale, $r=.394$, p. $=.01$. Hypothesis 4 was accepted.

\section{DISCUSSION}

The uniqueness of traditional and non-traditional students has inspired a movement in nursing education toward investigating learning styles and preferences of students. This movement is based on the assumption that preferences for a particular approach to learning may influence the degree of learning that takes place.

Constructivism theory may explain the rejection of Hypothesis 1. According to this theory, a deep approach to learn depends crucially on pre-existing skills and knowledge. If these are lacking, the student cannot carry out an intention to understand and may have to fall back on superficial approaches to the learning task. This study showed that graduate students have a mixed approach to academic tasks as demonstrated by the high scores on each style. They demonstrated versatile learning styles with clear evidence of deep level of understanding, reflecting a personal interpretation of topics covered, but also a preference toward the use of a surface approach to complete the academic task. The lack of significant statistical differences among the learning styles may be related to at least two possible reasons. First, there is the conceptual nature of learning where inadequate background knowledge in a field may be influencing both the student's intention and the process to carry out that intention. A student's prior knowledge and motivation, e.g. his/her historical and dialectical "being", may influence 
Table 4 - Correlation Matrix for Personality Dimensions (USA-2001)

\begin{tabular}{|c|c|c|c|c|c|c|c|c|c|}
\hline & SE-O & SE-CT & SE & AM & AM-I & AM-PR & AM-E & SA & $\mathrm{CA}$ \\
\hline $\begin{array}{l}\text { Self-Efficacy, } \\
\text { Organization (SE-O) }\end{array}$ & 1.00 & $.432^{* *}$ & $.343^{*}$ & .215 & .153 & .247 & .006 & $.428^{* *}$ & -.199 \\
\hline $\begin{array}{l}\text { Self-Efficacy, Critical } \\
\text { Thinking (SE-CT) }\end{array}$ & & 1.00 & $.471 * *$ & $.321 *$ & .220 & $.349 *$ & .059 & $.512^{*}$ & -.057 \\
\hline Self-Esteem (SE) & & & 1.00 & $.311^{*}$ & $.394 * *$ & .162 & .009 & $.296^{*}$ & $-.416^{*}$ \\
\hline $\begin{array}{l}\text { Academic } \\
\text { Motivation (AM) } \\
\text { Interest (AM-I) } \\
\text { Pers. Resp. (AM-PR) } \\
\text { Energy(AM-E) }\end{array}$ & & & & 1.00 & $\begin{array}{l}.732^{* *} \\
1.00\end{array}$ & $\begin{array}{l}.817^{* *} \\
.286^{*} \\
1.00\end{array}$ & $\begin{array}{c}.570^{* *} \\
.043 \\
.504^{*} \\
1.00\end{array}$ & $\begin{array}{l}.164 \\
.158 \\
.210 \\
-.117\end{array}$ & $\begin{array}{l}.104 \\
.013 \\
.085 \\
.187\end{array}$ \\
\hline $\begin{array}{l}\text { Self-Assertion (SA) } \\
\text { Conventional } \\
\text { Attitudes (CA) }\end{array}$ & & & & & & & & 1.00 & $\begin{array}{r}-.273 \\
1.00\end{array}$ \\
\hline
\end{tabular}

learning outcome more than learning style preference. Graduate students may be using surface and deep approach to learn depending on the teaching strategies applied in several subjects of the program and on their previous knowledge of the subject. It is important to recall that what is labeled "learning styles" are preferences of learning that have been learned, and that everyone is capable of going beyond the particular style preferred at the time.

Second, the IL- $\mathrm{R}$ is a 90 item closed-ended questionnaire consisting of self-descriptive statements to which the subject responds to dichotomous items that require a restrictive choice between two responses: yes or no. A 5-point Likert scale might be more appropriate, as this would have provided respondents with the option to indicate the degree to which their learning styles are preferred. The closed-ended questions force respondents to limit their range of view. Perhaps, preferences in learning styles would be better evaluated using a qualitative research design.

The rejection of Hypothesis 2 correlated with the findings of a previous study where no relationships were found between age and career experience and differences in adults learning preferences ${ }^{(18)}$. The expectation of an increase in reflective style as the result of increased years of professional practice may be erroneous. Professional practice may not be enough to develop a higher level of thinking. The framework of professional practice and graduate classes may not be supportive of these higher levels of thinking. Perhaps nurse educators and administrators need to develop different teaching and learning abilities to encourage themselves and people instructed by them to develop more reflexive learning styles.
Hypothesis 3 may have been rejected because background variables, such as the educator's philosophy of learning, academic program and curriculum design may be playing a role to explain the use of agentic learning through out the program.

The finding that Hypothesis 4 was accepted suggested that academic motivation is related to self-esteem. Learning is a natural lifelong process and this can be enhanced and facilitated through construction of a healthy self-esteem as well as motivation. Those who do not have need to expend their energy protecting themselves from fears and frustration will have more available learning strategies as well as motivation to improve their learning competences.

\section{CONCLUSION}

One major difficulty in conducting this study and interpreting results was the lack of previous studies applying constructivism concepts in the learning process of nursing students. Although much information is available in the education literature about learning theories, most nursing research continues to be based upon the behavioral theory of learning.

Nurse educators must objectively identify their students' learning styles and connect this with learning outcomes in order to improve the quality of nursing education. This may be accomplished through the use of qualitative methods that would allow educators to identify students' perceptions of their learning capacities. Analysis of comments made during open-ended interviews would lead the investigator to uncover learning preferences that students may not report using more quantitative methods. Findings from qualitative studies could then be used to develop more valid quantitative instruments for future 
research and larger studies.

\section{REFERÊNCES}

1. Vogt E. Learning out of context. In: Chawla S, Renesch J, editors. Learning organizations: developing cultures for tomorrow's workplace. Portland: Productivity Press; 1995. p.79-90.

2. Freire P. Teachers as cultural workers: letters to those who dare teach.: Westview Press; 1998.

3. Cobernn W. Contextual constructivism. In: Tobin K, editor. The practice of constructivism in science education. Washington: American Association for the Advancement of Science; 1993. cap. 6, p. 59-75.

4. Cobb P. An Exchange: Constructivism in mathematics and science education. Educ Res. 1994; 23(7): 13-20.

5. Tobin K, Tippins D. Constructivism as a reference for teaching and learning. In: Tobin K, editor . The practice of constructivism in science education. Washington: American Association for the Advancement of Science; 1993. cap. 3, p. 39-50.

6. Yager RE. Constructivism and the learning of science. In: Glynn SM, Duit R, editors . Learning science in the schools: research reforming practice. Mahwah, NJ: Lawrence Erlbaum Associates; 1995. p. 35-58.

7. Clement JJ. Non-formal reasoning in experts and in science students: the use of analogies, extreme cases, and physical intuition. In: Voss J, Perkins D, Segal J, editors. Informal reasoning and education. New Jersey: Lawrence Erlbaum Associates; 1991. cap. 10, p. 334-62.
8. Brown AL, Campione JC. Communities of learning and thinking, or a context by any other name. In: Kuhn D, editor. Developmental perspectives on teaching and learning thinking skills: contribution to human development. New Jersey: Lawrence Erlbaum Associates; 1990. v.21, cap. 7, p. 108-26.

9. Anderson CW, Smith EL. Teaching science. In: RichardsonKoehler V, editor. Educator's handbook: a research perspective. New York: Longman; 1987. cap.5, p. 84-111.

10. Bruner JS. On knowing: essays for the left hand. Cambridge, Mass: Harvard University Press; 1962.

11. Piaget J. Aprendizagem e conhecimento. Rio de Janeiro: Freitas Bastos; 1974.

12. Vygotsky LS. Mind in society: the development of higher psychological processes. Cambridge, Mass.: Harvard University Press; c1978.

13. Vygotsky LS. Thought and language. Cambridge, Mass: MIT Press; 1986.

14. Jonassen DH. Objectivism versus constructivism: do we need a new phylosophical paradigm? Educ Technol Res Dev. 1991; 39(3): 5-14.

15. Freire P. Pedagogia do oprimido. Rio de Janeiro: Paz e Terra; 1990.

16. Schmeck RR, Ribich FD, Ramanaiah N. Development of a self-report inventory for assessing individual differences in learning processes. Appl Psychol Meas. 1977; 1(3): 413-31.

17. Schmeck RR, Geisler-Brenstein E. The revised inventory of learning processes manual. Carbondale, IL: Individuation Technologies; 1995.

18. Merritt SL. Learning style preferences of baccalaureate nursing students. Nurs Res.1983; 32(6): 367-72. 